\title{
The DLGAP family: neuronal expression, function and role in brain disorders
}

\author{
Andreas H. Rasmussen ${ }^{1}$, Hanne B. Rasmussen ${ }^{2}$ and Asli Silahtaroglu ${ }^{1^{*}}$ (D)
}

\begin{abstract}
The neurotransmitter glutamate facilitates neuronal signalling at excitatory synapses. Glutamate is released from the presynaptic membrane into the synaptic cleft. Across the synaptic cleft glutamate binds to both ion channels and metabotropic glutamate receptors at the postsynapse, which expedite downstream signalling in the neuron. The postsynaptic density, a highly specialized matrix, which is attached to the postsynaptic membrane, controls this downstream signalling. The postsynaptic density also resets the synapse after each synaptic firing. It is composed of numerous proteins including a family of Discs large associated protein 1, 2, 3 and 4 (DLGAP1-4) that act as scaffold proteins in the postsynaptic density. They link the glutamate receptors in the postsynaptic membrane to other glutamate receptors, to signalling proteins and to components of the cytoskeleton. With the central localisation in the postsynapse, the DLGAP family seems to play a vital role in synaptic scaling by regulating the turnover of both ionotropic and metabotropic glutamate receptors in response to synaptic activity. DLGAP family has been directly linked to a variety of psychological and neurological disorders. In this review we focus on the direct and indirect role of DLGAP family on schizophrenia as well as other brain diseases.
\end{abstract}

Keywords: DLGAP1, DLGAP2, DLGAP3, DLGAP4, SAPAP, PSD, GKAP, Schizophrenia, Scaffold proteins, Synaptic scaling

\section{Introduction}

The postsynaptic density (PSD) is a highly specialized matrix that is involved in transmission of neuronal signals across the synaptic junction. The PSD is found in the synaptic terminal of postsynaptic neurons. A variety of proteins is expressed in the PSD for transmitting neuronal signals from the PSD to the soma or other parts of the neuron. The PSD scaffolding proteins, Discs large scaffold proteins (DLGs) and the family of Src-homology (SH3) and multiple ankyrin repeat domain proteins (SHANK) are essential for proper function of both the ionotropic N-methyl-D-aspartate (NMDA) and $\alpha$-amino-3-hydroxy-5-methyl-4-isoxazolepropionic acid (AMPA) receptors and the metabotropic glutamate receptors (mGluRs) [1-4]. The family of Discs large associated proteins (DLGAPs) are also important scaffold proteins in the PSD. There are five DLGAP proteins, DLGAP1 - DLGAP5 where DLGAP1 - DLGAP4 (DLGAP1-4) proteins interact directly with both DLG and SHANK through their multiple domains $[2,5,6]$. Via

\footnotetext{
* Correspondence: asli@sund.ku.dk

${ }^{1}$ Department of Cellular and Molecular Medicine, Faculty of Medical and Health Sciences, University of Copenhagen, DK-2200 Copenhagen, Denmark Full list of author information is available at the end of the article
}

interaction partners, DLGAP1-4 proteins are likely to play a role in multiple processes of the PSD. For example, neuronal DLGAP proteins have key roles in synaptic scaling $[7,8]$. DLGAP1-4 proteins have also been linked to a variety of neurological disorders including schizophrenia, autism spectrum disease (ASD), trichotillomania, obsessive compulsive disorder (OCD) and cerebellar ataxia [9-14] (see Table 1). Here we present the existing knowledge on the expression, function and the regulation of DLGAP1-4 in the brain. We also review the link of DLGAP1-4 to the various neurological disorders. DLGAP5 is not included in this review since it is mainly linked to various types of cancers and does not seem to play an important role in neuronal signalling [15-17].

\section{Nomenclature}

The DLGAP protein family is known under several different names. Initially DLGAP1 was named Guanylate kinase associated protein (GKAP) since it interacts with the guanylate kinase (GK) domain of SAP90/PSD-95 [5]. Shortly after, three other similar proteins were and the family of four proteins was subsequently named as SAP90/PSD95-associated 
Table 1 Table with the DLGAP subtypes expressed in the brain i.e. DLGAP1-4 and the corresponding CNS diseases and affected brain regions

\begin{tabular}{|c|c|c|c|}
\hline DLGAP subtype & CNS disease & Brain region affected & References \\
\hline \multirow[t]{3}{*}{ DLGAP1 } & Schizophrenia & Nucleus accumbens & [9] \\
\hline & Alzheimer's disease & Frontal cortex & [114] \\
\hline & Major depressive disorder & Hippocampus & {$[115]$} \\
\hline \multirow[t]{4}{*}{ DLGAP2 } & Schizophrenia & $n a^{*}$ & [99] \\
\hline & Fragile $\mathrm{x}$ mental retardation & Hippocampus & [116] \\
\hline & Post traumatic stress disorder & Hippocampus & [102] \\
\hline & Autism spectrum disease & $n a^{*}$ & {$[10,100,101]$} \\
\hline \multirow[t]{4}{*}{ DLGAP3 } & Trichotillomania & Striatum & {$[11,12]$} \\
\hline & Obsessive compulsive disorder & Striatum & {$[11,13,106]$} \\
\hline & Parkinson's disease & $n a^{*}$ & [117] \\
\hline & Schizophrenia & na* & {$[98]$} \\
\hline \multirow[t]{2}{*}{ DLGAP4 } & Cerebellar ataxia & Cerebellum & [14] \\
\hline & Bipolar disorder (indirectly linked) & $n a^{*}$ & [118] \\
\hline
\end{tabular}

na* No proven affected brain region. DLGAP1 is thought to be involved in schizophrenia starting from nucleus accumbens, Alzheimer's disease in frontal cortex and major depressive disorder originating from hippocampus. DLGAP2 is linked to multiple diseases. First schizophrenia with no proven affected brain region, second autism spectrum disease also with no proven affected brain region and finally fragile $\mathrm{x}$ mental retardation and post-traumatic stress disorder both originating from the hippocampus. DLGAP3 is proven to be involved in both trichotillomania and OCD both starting in the striatum. DLGAP3 has also been linked to Parkinson's disease. Finally, DLGAP4 is proven to be involved in cerebellar ataxia coming from cerebellum and indirectly to bipolar disorder via the microRNA miR-1908-5p. The relevant references are linked in the fourth column, respectively

protein 1-4 (SAPAP1-4) [18]. DLGAP1 is, however, still referred to as GKAP in the literature. PSD-95 is also named Discs large scaffold protein 4 abbreviated DLG4. Therefore, the SAPAP family proteins were named discs large homolog associated protein (DLGAP) 1-4. PSD-95 will in this work be referred to as DLG4 and GKAP/SAPAP1-4 will be referred to as DLGAP1-4.

\section{DLGAP chromosomal localisation, protein homology and conservation}

Four DLGAP proteins are found in the human brain, which are all encoded from a different locus. This section contains an overview of the chromosomal locations and mRNA transcript variants of DLGAP genes in human. The DLGAP proteins have a high sequential homology that we will review in detail along with the conservation of the DLGAP family in mammals and vertebrates.

\section{Chromosomal localisation and mRNA transcripts}

The DLGAP1-4 genes are located on 4 different chromosomes. DLGAP1 is located on the short arm of chromosome 18 within the band 11.31 (18p11.31) and has 9 human transcript variants spanning from 2253 nucleotides to 6628 nucleotides (see Fig. 1a). DLGAP2 is located on the short arm of chromosome 8 , in the band 23.3 (8p23.3). Two transcript variants have been identified for DLGAP2 having only one exon difference. Transcript variant 1 has 12 exons and transcript variant 2 has 11 exons (see Fig. 1a). $D L G A P 3$ is located on chromosome 1 in the band 34.3 on the short arm (1p34.3). Only one human $D L G A P 3$ transcript has been identified so far (see Fig. 1a). The DLGAP4 gene is situated on the long arm of chromosome 20 within the band 11.23 (20q11.23). Three transcript variants with varying lengths from 3044 nucleotides to 5080 nucleotides have been found in human (see Fig. 1a).

\section{DLGAP protein homology}

The many mRNA transcripts of DLGAP1-4 encode DLGAP proteins with various lengths and domains (see Fig. 2a). The pairwise homology between the DLGAP proteins differ by 26 to $48 \%$. DLGAP1 compared to DLGAP2 show the highest homology and DLGAP3 compared to DLGAP4 show the lowest homology (see Fig. 1b). DLGAP1-4 have 3 domains, a 14 amino acids repeat domain, a dynein light chain (DLC) domain and a GKAP homology (GH1) domain (see section 4.1). Especially the GH1 domain by which the DLGAP proteins are characterized, shows a high degree of homology i.e. 61 to $75 \%$. In addition, the last 40 residues next to the C-terminal also show a high degree of homology (see Fig. 1d).

\section{Conservation}

DLGAP1-4 are important proteins in the postsynaptic density. They act as scaffold proteins and are involved in signalling to and from glutamate receptors [19]. The 
a
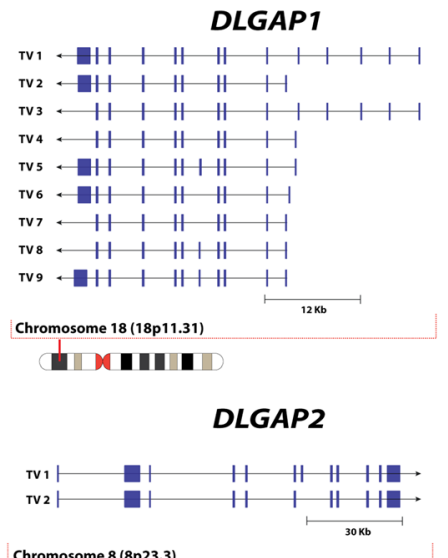

Chromosome 8(8p23.3) | IIIIMIIIIIIII||III

DLGAP3

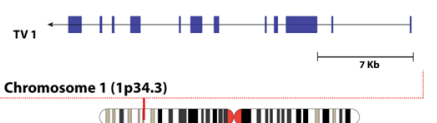

DLGAP4

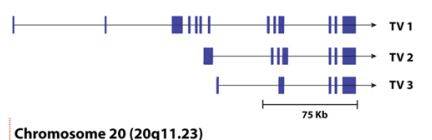

and b

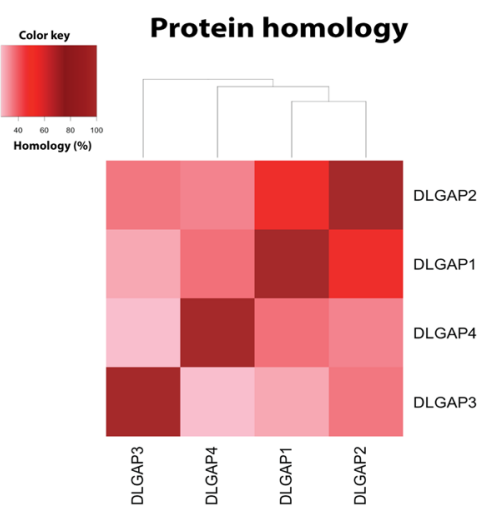

DLGAP protein conservation

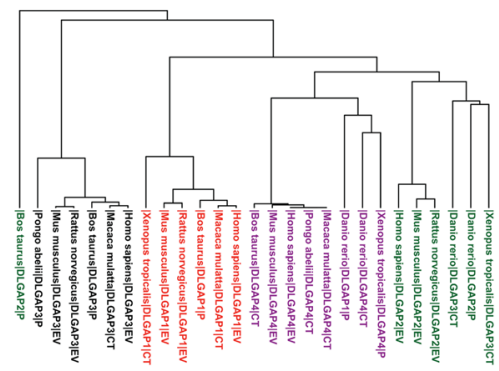

d

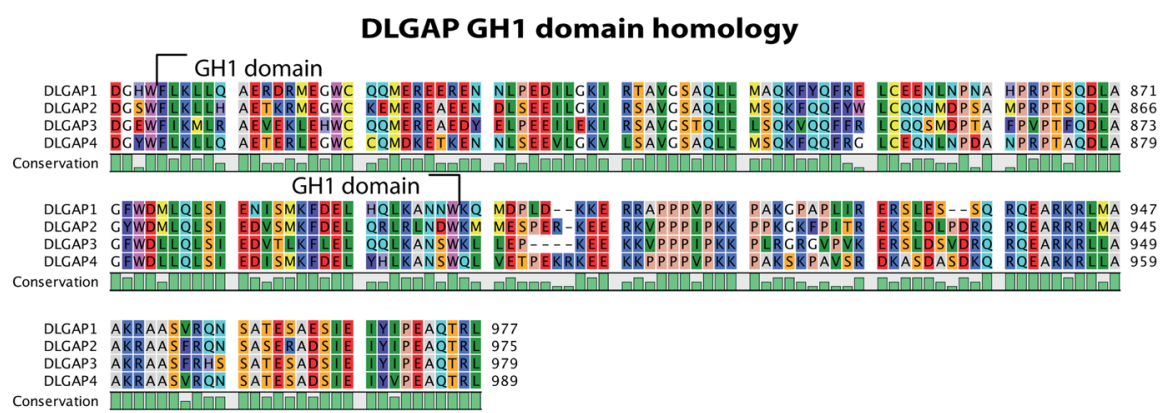

Fig. 1 a Pictogram of chromosome 18,8,1 and 20 and the four DLGAP1-4 loci, respectively. DLGAP1 is located on chromosome 18 and transcript variants 1 to 9 are illustrated. DLGAP2 is found on chromosome 8 and has two transcript variants. The DLGAP3 gene is located on chromosome 1 and has one transcript variant. DLGAP4 is located on chromosome 20 and has 3 transcript variants. $\mathbf{b}$ Heatmap showing the homology in percentage between the longest isoform, isoform a, of DLGAP1-4 proteins respectively. The color key indicates the respective percentage to each colour. The heatmap is created in RStudio v.0.99.484 with data from a multiple alignment made with clustal omega v.1.2.1. DLGAP1 isoform a: 977 amino acids (NP_004737.2), DLGAP2 isoform a: 975 amino acids (NP_004736.2), DLGAP3 isoform a: 979 amino acids (NP_001073887.1) and DLGAP4 isoform a: 989 amino acids (NP_055717.2). c Phylogenetic tree of DLGAP1-4 protein conservation in following species; Homo sapiens (NP_004737.2, NP 004736.2. NP_001073887.1, NP_001035951.1), Macaca mulatta (AFE64413.1, AFJ72104.1, AFE64177.1), Bos taurus (NP_001 179558.1, DAA17363.1, NP_001179367.1, AAl26739.1), Rattus norvegicus (NP_075235.3, NP_446353.2, NP_775161.2), Mus musculus (NP_808307.2, NP_766498.2, AAH57615.1, NP_001035953.1), Pongo abelii (XP_009251088.1, NP_001127321.1), Xenopus tropicalis (NP_001123829.1, NP_001106458.1, XP_012827022.1) and Danio rerio (NP_001189384.1, XP_009291347.1, NP_001038179.1, AAl33919.1). EV: Experimentally validated, CT: Conceptual Translation, P: Predicted from genomic sequence. The phylogenetic tree is created in RStudio v.0.99.484 with data from a multiple alignment made with clustal omega v.1.2.1. d Figure of multiple alignment of DLGAP1-4 GH1 domain and C-terminal. The sequence homology of the GH1 domain is 61 to $75 \%$ between DLGAP1 - DLGAP4. The alignment and data is generated in clustal omega v.1.2.1 and visualized in CLC sequence viewer v.7.6

DLGAP proteins are conserved between species most likely because their function is highly essential. DLGAP proteins have been experimentally found or predicted from genomic sequences in Homo sapiens, Macaca mulatta, Pongo abelii, Bos taurus, Rattus norvegicus, Mus musculus and in the two vertebrates Danio rerio and Xenopus tropicalis (see Fig. 1c). DLGAP1-4 was originally found in rat $[5,18]$ but most research have 


\section{a}

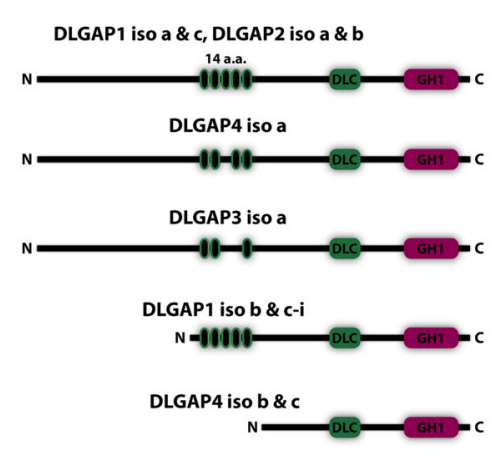

b

\section{Scaffold protein interactions}

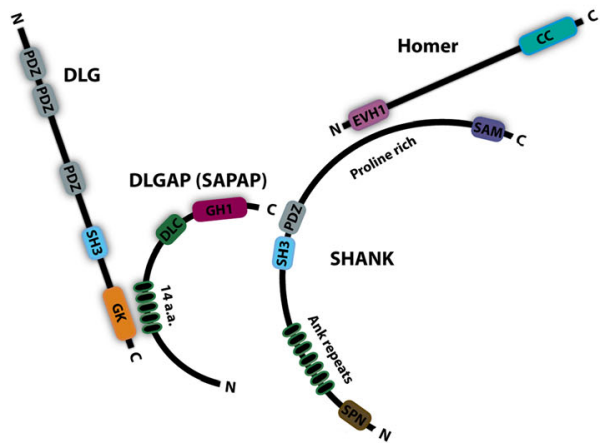

Fig. 2 a Pictogram of the DLGAP1-4 proteins with their respective domains. The DLGAP1-4 proteins have a 14 amino acid repeat domain (14-a.a. repeats) with 0 to 5 repeats depending on the DLGAP isoform, a Dynein light chain (DLC) domain and a GKAP homology domain 1 (GH1). b Illustration of how the four proteins interact. DLGAP binds via the C-terminal to the PDZ domain of SHANK. The 14-a.a. repeat domain of DLGAP binds the GK domain of DLG. Homer binds with the EVH1 domain to the proline rich domain of SHANK

since then been conducted in mouse and human where the genes and proteins also are described best.

\section{Domain overview and protein interaction}

The DLGAP1-4 proteins contain several characterized domains that enable them to interact with numerous proteins in the PSD either directly or indirectly via other scaffold proteins (see Fig. 2a-b). Some of these interacting proteins, namely the DLG4 protein, the SHANK family, the Homer family and the Stargazin protein will also be reviewed here. These proteins all have domains that have the capability to link DLGAP1-4 to the three major glutamate receptors in the PSD, namely the NMDA receptor, the AMPA receptor and the group I mGluRs $[1-3,5,20,21]$.

\section{The DLGAP family}

As mentioned, the DLGAP proteins have three known domains, a 14-a.a. repeat domain, a DLC domain and a GH1 domain (see Fig. 2a). With the 14-a.a. domain DLGAP proteins are capable of binding the GK domain of DLG1, DLG2 and DLG4 [5, 22-24]. Depending on the isoform, the 14-a.a. domain can be located in the middle of the protein or near the $\mathrm{N}$-terminal. For example, in the long DLGAP1 isoforms (isoform a \& c) the repeats are located in the middle whereas in the short isoforms (isoform b, d-i) the repeats are located near the N-terminal. DLGAP1 has five 14-a.a. repeats but some of the repeats are missing in the other DLGAP proteins. For example, the long DLGAP4 isoform a lacks the repeat number 3 and the short isoforms $b$ and $c$ do not contain any of the 5 repeats (see Fig. 2a) [18]. This diversity in repeats may contribute to their individual function and binding affinity to DLG4 at the synapse. The second domain, the DLC domain is located downstream of the repeats. This DLC domain interacts directly with DLC, a motor protein subunit found in the dendrites and PSD [25]. The last domain, the GH1 domain, is found at the C-terminal. GH1 is composed of 4 alpha helices and display a high sequence homology between the DLGAP proteins as previously mentioned (see Figs. 1d and 2a \& b). However, the role of the GH1 domain is still unknown $[5,6,26]$.

\section{Proteins interacting with the DLGAP family}

The DLG family The DLG family is a group of proteins also known as membrane-associated guanylate kinases (MAGUKs). Three of these proteins; DLG1, DLG2 and DLG4 also known as SAP97, PSD-93 and PSD95, respectively, are known to interact directly with DLGAP [22-24]. The DLG proteins are important proteins in the PSD because they link other scaffold proteins and signalling molecules either directly or indirectly to the membrane bound ion channels. DLGs are known to stabilize the glutamate receptors upon binding and they may also trigger synaptic growth by modulation of growth-related proteins in the PSD [4]. DLGs, like DLGAP proteins, are also involved in synaptic scaling [4, 27-29], which is a process that is associated with schizophrenia [30]. The link of DLG1, DLG2 and DLG4 to schizophrenia has been well documented [31-36]. Additionally, DLG4 has been linked to ASD [37].

DLGs have three different types of domains where the first type is the Postsynaptic density protein; Drosophila disc large tumor suppressor; Zonula occludens-1 protein (PDZ) domain. In addition, DLGs have a Src Homology 3 (SH3) domain and a GK domain. DLGs have 3 PDZ domains (see Fig. 2b). The second PDZ domain binds the C-terminal of NMDA receptors [1]. Downstream of the PDZ domains, the SH3 domain is located, which has 
multiple binding partners including the A kinase anchor protein 150, AKAP150 [38]. Also, DLGs can create intramolecular interactions by binding the $\mathrm{SH} 3$ domain to the GK domain [39]. Most likely DLG proteins are also able to dimerize via SH3:GK interactions. With its GK domain DLGs interact directly with most DLGAP proteins through the 14-a.a. repeat domain [5] (see Fig. 2b). With the GK domain and the second PDZ domain DLGs acts as scaffolds between the DLGAP proteins and the NMDA receptors and AMPA receptors via Stargazin (see section 4.2.4) [3].

The SHANK family DLGAP proteins bind a second family of proteins, the SHANK proteins [2]. Most SHANK proteins are highly expressed in the PSD and they are important for the maturation of the PSD. Overexpression of SHANK leads to earlier maturation of the postsynapse by recruitment and interaction with other scaffold proteins. There are three SHANK genes in humans that encode 3 SHANK proteins (SHANK1-3). SHANK3 has been linked to schizophrenia whereas SHANK1-3 have all been linked to ASD [40].

SHANK proteins do not directly bind to glutamate receptors in the PSD but SHANK1-3 have the capability to link the ionotropic glutamate receptors to the metabotropic glutamate receptors by dimerization and molecular interaction with other scaffold proteins. Compared to DLGAP1-4 and DLG4, SHANK1-3 are longer proteins and have more domains (see Fig. 2b). Close to the N-terminal SHANK1-3 has a SHANK/ProSAP (SPN) domain followed by 7 Ankyrin (Ank) repeats. Like DLG4, SHANKs also have a SH3 domain and one PDZ domain. Downstream of PDZ, a proline rich domain is found, which is followed by a sterile alpha motif, SAM, domain close to the C-terminal. The SPN domain is largely uncharacterized. However, two binding partners have been reported for the Ank repeats, the protein alpha-Fodrin [41] and the Sharpin protein [42]. Both proteins bind to the cytoskeleton [43, 44]. Interestingly, the long isoform of SHANK2 with the Ank repeats, SHANK2E, seems not to be expressed in the PSD but mostly in epithelial cells [45]. SHANK1-3 has one SH3 domain like DLG4. In SHANK1-3, this domain mediates interaction with the PSD scaffold protein Densin180. Densin-180 can promote dendritic branching. This feature is however negatively regulated when Densin180 interacts with SHANK proteins [46]. Close to the SH3 domain, SHANK1-3 have a PDZ domain. The Cterminal of DLGAP1-4 interacts directly with SHANK1-3 via this domain [2] (see Fig. 2a \& b). Hereby SHANK1-3 are linked to the postsynaptic plasma membrane via DLGAP1-4, PSD-95 and NMDA receptors. Downstream close to the N-terminal SHANK1-3 have a
SAM domain, which bind other SAM domains for multimerization of SHANK1-3 proteins [47]. Multimerization of SHANK1-3 proteins can generate a network in the PSD that link numerous proteins to the postsynaptic receptors. This network also enables downstream signalling cascades from the postsynaptic glutamate receptors in which DLGAP proteins are an important element. Finally, SHANK1-3 also connects to the Homer family, via the proline rich domain [20].

The Homer family The Homer family consists of 3 proteins (Homer1-3) with various isoforms encoded by 3 HOMER genes. The Homer proteins have a function in neuronal development [48] and they play a central role in the PSD because these proteins bind to group I mGluRs and regulate the activity hereof $[49,50]$. Homer1 has been linked to mental retardation syndromes in Fragile X mental retardation patients and in Fragile mental retardation 1 (FMR1) knockout mice [51, 52]. Abnormal spine densities were found in the FMR1 knockout mice, which support the importance for Homer proteins in neuronal development and proper PSD function.

Homer1-3 have two known domains. The first domain is the highly conserved Ena/VASP Homology 1 (EVH1) domain and the second domain is a coiled coil (CC) domain (see Fig. 2b). The EVH1 domain is located near the $\mathrm{N}$-terminal and with this domain Homer1-3 interacts with the proline rich domain of SHANK1-3 [20]. In addition Homer1-3 have the ability to interact with group I mGluRs that also have a proline rich domain [21]. DLGAP1-4 is not directly associated with Homer1-3. However, Homer1-3 are interesting because they connect DLGAP1-4 to group I mGluR via SHANK1-3 (see Fig. 2b). Like DLG4 and SHANK1-3, Homer1-3 also have the capability to dimerize. The CC domain can bind other CC domains for homodimerization [53].

Stargazin DLGAP proteins indirectly interact with Stargazin via DLG4, which is interesting because it couples DLGAP proteins to the AMPA receptor. Stargazin is a tetraspanning transmembrane protein also known as calcium channel, voltage-dependent, gamma subunit 2. Stargazin shows structural resemblance to calcium channel, voltagedependent, gamma subunit 1 , which is a subunit in voltage gated calcium channels. Thus, it was first believed to be a calcium channel subunit [54], Stargazin is not a genuine subunit of calcium channels [55]. Stargazin is well known from the stargazer mouse, a model of ataxia and epilepsy where the Stargazin gene is deleted [56, 57]. Stargazin was found to interact with AMPA receptors and regulate their synaptic targeting, surface trafficking and trafficking to endosomes in ion channel scaling. This 
regulation require the C-terminal of Stargazin that interacts with the PDZ domain of DLG4 [3, 58-60]. Stargazin also plays an important role in the function of AMPA receptors. Stargazin can modulate the biophysical properties and channel gating of AMPA receptors [61-64]. Moreover, Stargazin can increase the efficacy of agonists on AMPA receptors and it can also act to slow down deactivation of AMPA receptors after glutamate binding $[62,65,66]$.

\section{DLGAP1-4 expression in the brain}

DLGAP1-4 are expressed throughout the body but in general they are expressed in much higher levels in the brain [6]. DLGAP1-4 are mainly localized in the dendrites and the postsynapse of excitatory synapses (see Fig. 3) $[18,67,68]$. In the brain the expression of DLGAPs is widespread and the different isoforms show a somewhat different expression pattern. In situ hybridization experiments on rat and mouse brain tissue show that Dlgap1 mRNA is expressed in cortex, hippocampus, olfactory bulb, striatum, thalamus as well as in both granule layer and Purkinje cells of cerebellum (see Table 2) [6, 68]. The expression of Dlgap 2 resembles that of Dlgap1 with expression in cortex, hippocampus and olfactory bulb. However, Dlgap 2 is highly expressed in the striatum and interestingly Dlgap 2 is the only Dlgap that is not expressed in the cerebellum and in the thalamus [68]. Expression of Dlgap3 mRNA is observed throughout the mouse brain including the cortex, thalamus, retina and olfactory bulb with high levels in the hippocampus, striatum and granule cells of cerebellum [68]. In cortex and cerebellum, the expression level of
DLGAP3 varies in the postnatal rat brain. Around 3 weeks after birth the expression level peaks [69]. There are three transcript variants expressed from the DLGAP4 locus, which are all present in the brain. Transcript variant 1 however, is totally brain specific whereas transcript variant 2 and 3 show tissue-wide expression [14]. In the brain DLGAP4 shows high expression in the hippocampus, striatum, thalamus, amygdala, substantia nigra and in the Purkinje cells of cerebellum [14, 18, 68, 69].

\section{Functional role of DLGAP proteins}

\section{DLGAP proteins are involved in ion channel scaling at the synapse}

The DLGAP1 protein is enriched in the synapse where it acts as a scaffold protein and contributes to synaptic scaling [8]. Synaptic scaling, a form of homeostatic synaptic plasticity, is a function of the excitatory synapses to reset the neuronal firing rate to "normal" levels. The firing rate is normalized by a change in the postsynaptic response in every synapse of a neuron. The change in postsynaptic response results from alterations in the activity of neurotransmitter receptors like AMPA and NMDA receptors. For example, NMDA receptor scaling is regulated via the number of NMDA receptors at the synapse. The number of NMDA receptors functions as a bidirectional feedback mechanism. When the synapse is inactive, NMDA receptors are transported from the endoplasmic reticulum to the synapse. When the synapse is active, synaptic NMDA receptors undergo endocytosis and export of NMDA receptors from the endoplasmic reticulum slows down [70].
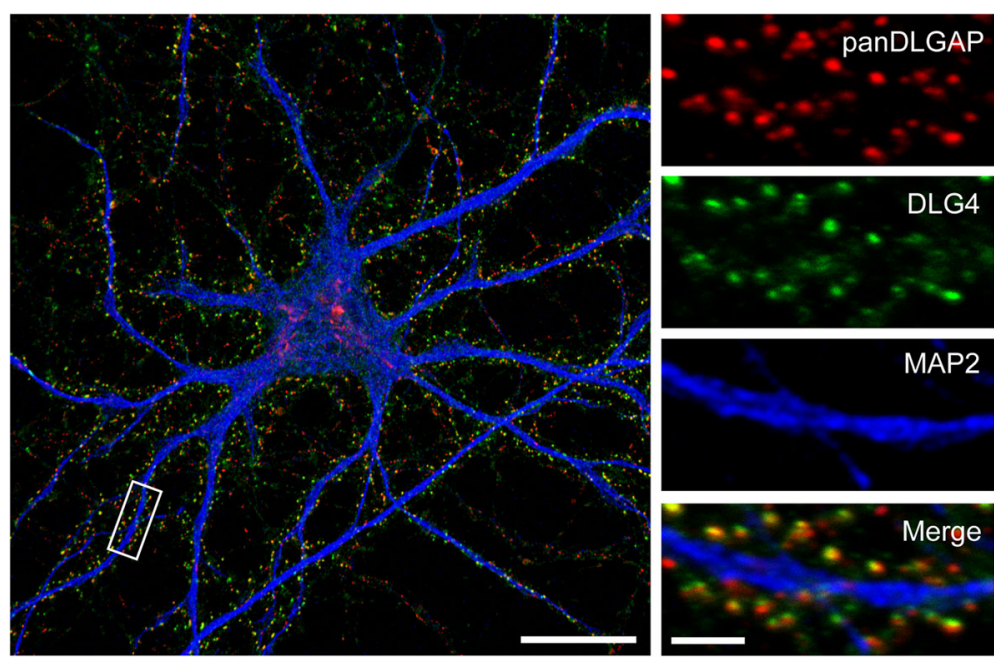

Fig. 3 DLGAPs are proteins of the postsynaptic density. The postsynaptic localization of DLGAPs in a cultured rat hippocampal neuron as revealed by a panDLGAP immunostaining. The excitatory postsynapses were visualized with an antibody directed against PSD-95 and MAP-2 used as a dendritic marker. Left scale bar, $20 \mu \mathrm{m}$; right scale bar, $3 \mu \mathrm{m}$ 
Table 2 The table shows where the DLGAP subtypes are expressed in the brain (Brain region, second column)

\begin{tabular}{|c|c|c|c|}
\hline DLGAP subtype & Brain region & Brain region & References \\
\hline \multirow[t]{6}{*}{ DLGAP1 } & Cortex & $\uparrow$ & \multirow[t]{6}{*}[6,68]{} \\
\hline & Hippocampus & $\uparrow$ & \\
\hline & Cerebellum & $\uparrow$ & \\
\hline & Olfactory bulbs & $\uparrow$ & \\
\hline & Striatum & $\downarrow$ & \\
\hline & Thalamus & M & \\
\hline \multirow[t]{4}{*}{ DLGAP2 } & Cortex & M & \multirow[t]{4}{*}[68]{} \\
\hline & Hippocampus & $\uparrow$ & \\
\hline & Olfactory bulbs & M & \\
\hline & Striatum & $\uparrow$ & \\
\hline \multirow[t]{7}{*}{ DLGAP3 } & Cortex & M & \multirow[t]{7}{*}[68]{} \\
\hline & Thalamus & M & \\
\hline & Retina & M & \\
\hline & Olfactory bulbs & M & \\
\hline & Hippocampus & $\uparrow$ & \\
\hline & Striatum & $\uparrow$ & \\
\hline & Cerebellum & $\uparrow$ & \\
\hline \multirow[t]{6}{*}{ DLGAP4 } & Hippocampus & $\uparrow$ & \multirow[t]{6}{*}[14,18,69]{} \\
\hline & Striatum & $\uparrow$ & \\
\hline & Cerebellum & $\uparrow$ & \\
\hline & Thalamus & M & \\
\hline & Amygdala & M & \\
\hline & Substantia nigra & $\downarrow$ & \\
\hline
\end{tabular}

In the third column the expression level for the specific brain region is

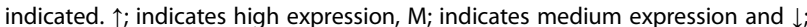
indicates low expression levels. In the fourth column relevant references are linked

Synaptic scaling and the turnover of NMDA receptors are supplemented by a turnover of proteins in the PSD. The level of the scaffold protein DLG4, which interacts with the cytoplasmic tail of NMDA receptors (reviewed here: Sheng [71]) is reduced during NMDA receptor activity. Reduction of DLG4 at synaptic sites is a result of ubiquitination and proteasomal degradation [72, 73]. DLGAP proteins appear to control the DLG4 degradation indirectly. Upon dissociation of the DLGAP 14-a.a. domain from the DLG4 GK domain, both DLGAP1 and DLG4 are ubiquitinated and degraded [8, 74]. The DLG4DLGAP1 interaction is disrupted by phosphorylation of DLGAP1, which is catalyzed by the $\mathrm{Ca}^{2+} /$ calmodulindependent protein kinase II alpha chain ( $\alpha$ CaMKII). $\alpha$ CaMKII is activated by influx of $\mathrm{Ca}^{2+}$ ions through the NMDA receptors upon activation. The scaffold protein SHANK is also downregulated at the synapse as a result of DLGAP1 phosphorylation [8]. The phosphorylation most likely disrupts the interaction of the
C-terminal of DLGAP1 with the PDZ domain of SHANK (see Fig. 4a) [75].

During synaptic inactivation DLGAP1, DLG4 and SHANK are, like the NMDA receptors, accumulating at the synapse again. DLGAP1 seems to be the linker in this accumulation. However, DLGAP1, DLG4 and SHANK are equally dependent on each other for accumulation (see Fig. 4a) [76]. It is believed that the scaffold proteins and NMDA receptors have a fast turnover with a short lifespan at the synapse [77].

DLGAP1 turnover seems to be important in synaptic scaling mediated by influx of $\mathrm{Ca}^{2+}$ ions through the NMDA receptors but it also plays a role in AMPA receptor scaling. It is known that DLG4 indirectly binds to AMPA receptors through Stargazin [3]. Further, DLGAP proteins interact with DLG4 as described above and phosphorylation of DLG4 by protein kinase A (PKA) leads to removal of AMPA receptors from the membrane by endocytosis [72]. Research has also shown, that loss of DLGAP3 causes silencing of AMPA receptors at the postsynapse [78]. In addition, overexpression of mutant DLGAP1 in hippocampal neurons eliminate homeostatic regulation of AMPA receptor surface expression [8].

DLGAP proteins clearly have a central role in ion channel synaptic scaling including both NMDARs and AMPARs. This function of DLGAPs appears to be achieved in concert with DLG4, SHANK, $\alpha$ CaMKII and possibly Stargazin.

\section{DLGAP proteins control metabotropic glutamate receptor group I induced synaptic scaling}

The group I metabotropic glutamate receptors (mGluRs) belong to a class of receptors in the mGluR family that is involved in synaptic scaling [79]. mGluRs are G-protein coupled receptors (GPCR) that bind glutamate. Upon glutamate binding of group I mGluRs, phospholipase C (PLC) hydrolyses phospholipids in the membrane. Subsequently inositol 1,4,5-triphosphate (IP3) and diacyl glycerol (DAG) are released, which can lead to activation of protein kinase $\mathrm{C}$ (PKC) and increased intracellular levels of $\mathrm{Ca}^{2+}$ (see Fig. 4b). The group I mGluR family includes two receptors, namely mGluR1 and mGluR5. Group I mGluRs can modulate NMDA and AMPA receptor activity and induce synaptic scaling upon activation. The scaffold protein Homer seems to be required for group I mGluR induced synaptic scaling [79] and for the crosstalk between group I mGluRs and the NMDA and AMPA receptors [80]. The crosstalk is likely mediated through a DLG4-DLGAP-SHANK-Homer complex [21]. Homer binds to the C-terminal of group I mGluR [81] and the coupling of Homer to the group 


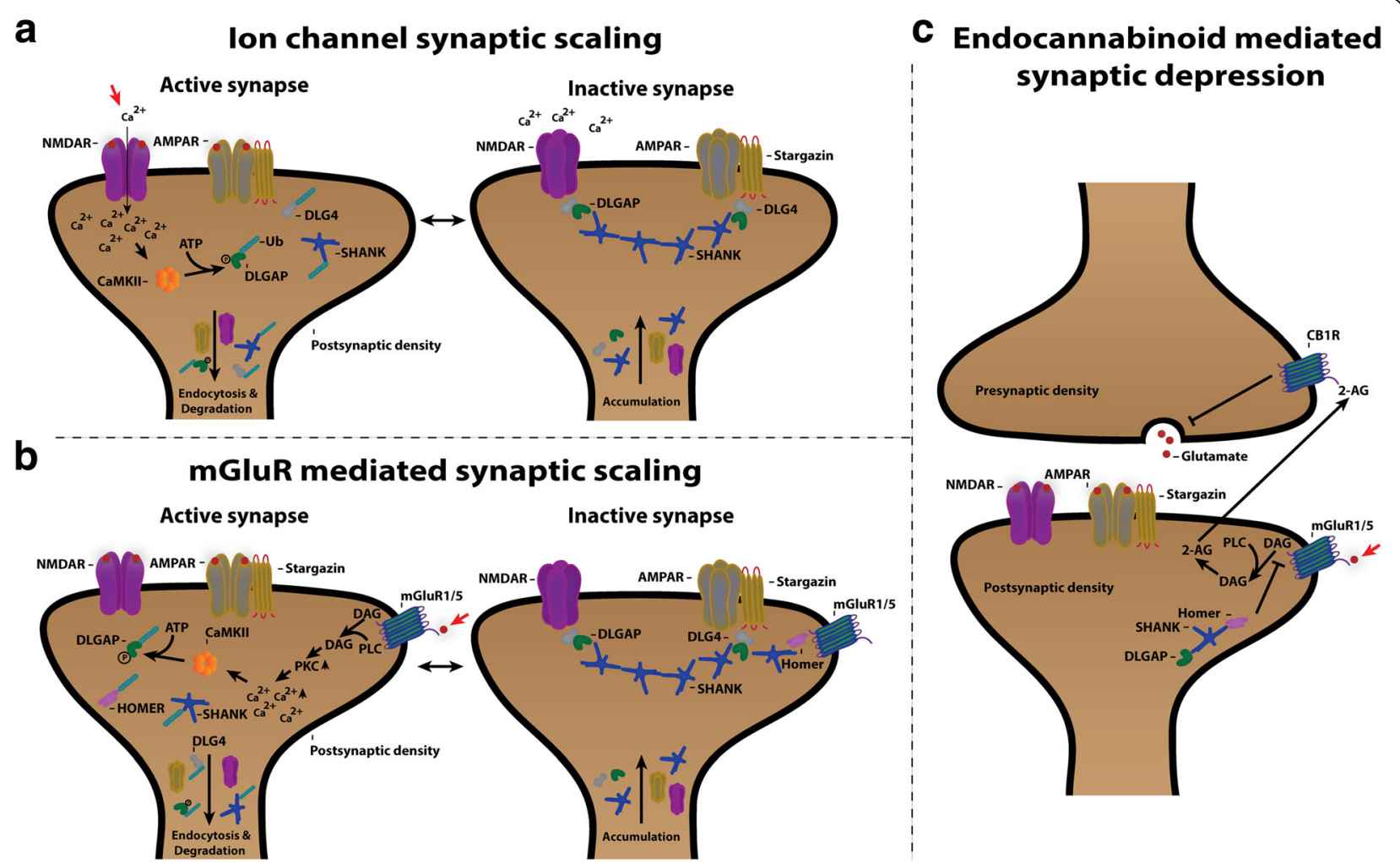

Fig. 4 a Proposed model of the states in ion channel mediated synaptic scaling. In the active synapse calcium influx through the NMDA receptor activates CaMKII that utilizes ATP to phosphorylate DLGAP that causes dissociation from DLG4 and SHANK and prones them for ubiquitination (Ub). Subsequently, DLGAP, DLG4 and SHANK are degraded, which results in endocytosis of the AMPA and NMDA receptors. During synaptic inactivation the scaffold proteins DLGAP, DLG4 and SHANK accumulate together with the AMPA and NMDA receptors that are incorporated in the membrane. $\mathbf{b}$ Proposed model of mGluR mediated synaptic scaling displayed as an equilibrium between the active and the inactive synapse. The synaptic scaling is initiated by activation of mGluR1/5 by glutamate followed by PLC-mediated membrane release of DAG. The release of DAG leads to activation of PKC and release of intracellular $\mathrm{Ca}^{2+}$. The increase in calcium ions activates CaMKIl that phosphorylates DLGAP and Homer. After phosphorylation DLGAP dissociates from DLG4 and SHANK, and Homer dissociates from mGluR1/5 and SHANK. DLGAP, DLG4, Homer and SHANK are then ubiquitinated (Ub) and degraded. With no intracellular bound scaffold proteins, NMDA receptors and AMPA receptors are internalised and removed from the synapse. In the inactive synapse after activation the scaffold proteins DLGAP, DLG4, Homer and SHANK accumulate together with AMPA receptors and NMDA receptors that are incorporated into the membrane. c Working model of endocannabinoid-mediated synaptic depression that is initiated by glutamate stimulation of mGluR1/5 that leads to PLC-mediated release of DAG. Then, DAG is converted to the endocannabinoid 2-AG that is transported to the synaptic cleft where it binds to the endocannabinoid receptor CB1R. After activation of CB1R, glutamate release from the presynapse to the synaptic cleft is halted, which leads to the depression. Presence of DLGAP in the PSD inhibits this endocannabinoid synaptic depression most likely via a DLGAP-SHANK-Homer- mGluR1/5

I mGluR and other interaction partners in the PSD is, like for DLGAP1, also controlled by phosphorylation catalysed by CaMKII [82]. In addition to Homer, DLGAPs are also believed to play an important role in group I mGluR induced synaptic scaling. This is due to the essential binding to both DLG4 and SHANK, and research show that loss of DLGAP2 causes significant downregulation of Homer and AMPA receptors [83]. DLGAP's role in group I mGluR synaptic scaling is probably not much different from its role in ion channel scaling. DLGAPs are likely phosphorylated by CaMKII upon group I mGluR activation. Phosphorylation of DLGAP and Homer leads to degradation or removal of DLGAP, Homer, DLG4 and SHANK from the PSD. Upon degradation or removal of scaffold proteins, the NMDA and AMPA receptors are unstable and subsequently removed from the membrane via endocytosis (see Fig. 4b).

\section{The role of endocannabinoids in synaptic depression is guarded by DLGAP}

The group I mGluRs can regulate synaptic plasticity via release of intracellular $\mathrm{Ca}^{2+}$ as described above. Another way group I mGluRs can regulate synaptic plasticity is through endocannabinoid mediated synaptic depression. Endocannabinoids are a class of lipids that are synthesized from membrane-bound phospholipids. The synthesis occurs after activation of group I mGluRs where the phospholipids are 
converted into endocannabinoids via different cleaving mechanisms. For example, DAG that is released from the membrane by PLC after group I mGluR activation is converted to the endocannabinoid 2-Arachidonoyl glycerol (2-AG). After synthesis the endocannabinoids are transported into the synaptic cleft and to the presynapse where the endocannabinoid receptor 1 (CB1R) is located. The CB1R is a GPCR and upon endocannabinoid binding, downstream signalling is initiated. One downstream signalling cascade results in inhibition of neurotransmitter release from the presynapse (see Fig. 4c) [84]. The scaffold protein Homer1 that binds group I mGluRs seems to play a role in the endocannabinoid signalling [85]. Homer1 expression regulates endocannabonoid production as a result of mGluR stimulation. Besides Homer1, DLGAP3 also regulates endocannabinoid mediated synaptic depression. In Dlgap3 knockout mice, endocannabinoid-dependent synaptic depression is increased in the striatum in a mGluR dependent manner [7]. This indicates that the presence of DLGAP proteins in the PSD activates or promotes synaptic transmission by inhibiting mGluR-mediated endocannabinoid signalling. The scaffold protein SHANK binds both DLGAP and Homer why DLGAP3 most likely controls endocannabinoid signalling through a DLGAP3-SHANK-Homer-group I mGluR complex (see Fig. 4c).

\section{DLGAP proteins in neurological and psychiatric disorders}

The DLGAP proteins are expressed in the postsynapse and interact with several proteins involved in the function and maintenance of the NMDA, AMPA and group I mGluR glutamate receptors. DLGAPs play an important role in the PSD and even small changes in expression of DLGAPs could have severe consequences in the signalling within the PSD. It is therefore not surprising that all DLGAPs have been linked to various psychiatric and neurological disorders including schizophrenia, OCD and cerebellar ataxia (see Table 1) $[9,11,14]$.

\section{Schizophrenia and DLGAPs}

Schizophrenia is a widespread, complex mental disorder that is characterized by symptoms like delusions, hallucinations and abnormal social behaviour. It affects approximately $1 \%$ of the population worldwide [86]. Schizophrenia has a high degree of heritability however, a large fraction of patients do not have a family history which can be explained by sporadic mutations $[87,88]$.

Schizophrenia is functionally associated with the NMDA receptors $[89,90]$. One hypothesis behind the NMDA receptor influence in schizophrenia is explained by altered glutamate signalling as a result of reduced or increased incorporation of NMDA receptors in the postsynaptic membrane $[91,92]$. As explained in section 6 , DLGAPs influence NMDA receptor synaptic scaling via DLG4 and both DLG4 and DLGAP1 have been linked to schizophrenia. The DLG family members, DLG1 and DLG2, which also interact with DLGAPs and NMDA receptors [93-95] have been linked to schizophrenia as well [35-37].

Analysis of brain samples from post mortem schizophrenic patients revealed that the level of DLG4 was downregulated in anterior cingulate cortex [33]. Another study demonstrated increased expression of DLGAP1 in the nucleus accumbens [9]. Moreover, the expression level of DLG1 and DLG2 was also found to be significantly skewed in a schizophrenia rat model and in schizophrenic patients [32, 96-98]. The deregulation of DLGs and DLGAP1 in these patients could be an indication of malfunction of NMDA receptors. Especially the NMDA subunit, GluN2A shows altered expression in schizophrenic patients [91, 92]. The schizophreniarelated upregulation of DLGAP1 expression could be the result of a feedback mechanism where the neurons are trying to re-establish the normal function and signalling of the GluN2A containing NMDA receptor.

After the discovery of the potential role of DLGAP1 in schizophrenia, related gene family members have also been analysed extensively in genetic studies. Multiple single nucleotide variations (SNVs) have been reported in DLGAP2 and DLGAP3 genes in schizophrenia patient cohorts [99, 100]. In DLGAP3 two SNVs were identified in the C-terminal, one of which was located in a domain which is believed to affect the post-translational modification of the DLGAP3 protein. It was speculated that all the DLGAP3 SNVs would impact the interaction with protein kinases and thereby the function of DLGAP3 [99]. No functional studies have yet been conducted on DLGAP2 and DLGAP3 in relation to schizophrenia. DLGAP2 and DLGAP3 have only been linked to schizophrenia in genetic screens. Yet, genetic changes in DLGAP2 and DLGAP3 are considered as susceptibility factors for schizophrenia $[99,100]$.

\section{Other brain disorders and DLGAPs}

The DLGAPs have been linked to a number of brain disorders in addition to schizophrenia. DLGAP2 was identified as a candidate gene for ASD where patients display impaired social interaction and communication skills in addition to having stereotyped interests and behaviours $[10,101,102]$. 
Animal studies have pinpointed a link between DLGAP2 and post-traumatic stress disorder (PTSD), which is observed as a result of a traumatic experience. In a rat model of PTSD, a change in methylation and in expression of Dlgap2 was shown in the hippocampus [103]. In individuals with PTSD the hippocampus is known to be smaller and less activated [104-106]. Moreover, Dlgap2 knockout $\left(\right.$ Dlgap $\left.2^{-/-}\right)$mice showed deficits in learning, abnormal social behaviour and intense aggressive behaviour, which is characteristic for both ASD and PTSD [83].

Biochemical studies revealed that specific subunits in the AMPA and NMDA receptors, the scaffold protein Homer1 and $\alpha$ CaMKII were significantly downregulated in the Dlgap2 $2^{-/-}$mice resulting in disruption of both synaptic transmission and synaptic structure [83].

DLGAP3 has been associated with OCD, which arises from anomalous signalling in the striatum and develops into a phenotype where the patients need to check or perform certain things repeatedly. Dlgap3 knockout $\left(\right.$ Dlgap $\left.3^{-/-}\right)$mice showed increased self-grooming bouts compared to wild type mice, which resulted in lesions in their head and neck. In addition, the Dlgap $3^{-1-}$ mice exhibited increased anxiety-like behaviour, which is also characteristic for OCD [11].

Since Dlgap3 $^{-1-}$ mice showed OCD-like symptoms, patients with the grooming disorder, trichotillomania (hair-pulling disorder) and OCD were genotyped for SNVs in the DLGAP3 locus [12]. An association was found between variations in the DLGAP3 gene and trichotillomania, which appeared to be familial. However, a coherence between variants in the DLGAP3 gene and OCD was not obvious [12]. Other studies have nonetheless linked genetic variants in DLGAP3 to OCD-like symptoms. In patients with OCD and trichotillomania, multiple and rare missense mutations were found in the DLGAP3 gene [107].

The fourth DLGAP gene, DLGAP4, has been related to cerebellar ataxia. Our group had discovered a familial translocation between chromosome 8 and $20 \mathrm{t}(8: 20)$ segregating with early-onset cerebellar ataxia [108]. This translocation resulted in symptoms including ataxia, clumsiness, impaired hand coordination and tremors. The translocation disrupted the DLGAP4 locus and separated the promoter and the first exon from the rest in transcript variant 1 , which is brain-specific. In addition, the translocation disrupted the DLGAP4 promoter associated CpG island which lead to epigenetic changes and increased expression of the DLGAP4 transcript variant 2 [14].

The misregulation of DLGAP4 could very likely lead to altered surface expression of both ionoptropic and metabotropic glutamate receptors in the PSD. Deregulation of glutamate receptor turnover, could potentially be followed by a faulted glutamate signalling from the presynapse to the postsynapse leading to the reported phenotype. In fact, both loss of AMPA receptors and loss of group I mGluR signalling have previously been associated with cerebellar ataxia [109-111].

\section{Conclusions}

In this review we have focused on members 1 to 4 of the DLGAP protein family with regard to their function in the brain and involvement in neurological diseases. The DLGAP proteins have multiple domains and act as scaffold proteins in the PSD where they enable crosstalk between metabotropic and ionotropic glutamate receptors via other scaffold proteins including DLG4, SHANK and Homer $[1-5,21,47,49,50,58-60]$. DLGAPs are believed to control synaptic scaling as a result of NMDA receptor, AMPA receptor and group I mGluR activation $[3,5,7,8,58-60]$. Undoubtedly further research on this topic would be of great value to decipher the role of the individual DLGAP proteins and the interplay between the DLGAP proteins in neuronal synapses. To understand the implication of DLGAPs in neurological disorders will be of great importance. Multiple studies have been conducted on DLGAPs in relation to schizophrenia $[37,86,112-114]$. Specifically, there is heavy literature on involvement of DLGAP1 in schizophrenia and suggesting DLGAP2 as a candidate gene for ASD $[10,100,101]$ and PTSD [83, 102]. It is likely that mutations in DLGAP2 could lead to the symptoms seen in ASD and PTSD patients. The data convincingly depicts the DLGAP3 gene as a disease gene for both OCD and trichotillomania [11-13, 106]. In contrast to DLGAP1-3, the general literature on DLGAP4 is very limited. DLGAP4 is proposed as a candidate gene for cerebellar ataxia [14] but DLGAP4 was never investigated in studies of the Stargazer mouse, a mouse model of cerebellar ataxia $[3,54,56]$. More research and data is expected in the coming years to clarify the role of DLGAP1, 2, 3 and 4 in synaptic plasticity and their involvement in schizophrenia and neurological diseases.

\footnotetext{
Abbreviations

AMPA: a-amino-3-hydroxy-5-methyl-4-isoxazolepropionic acid; Ank: Ankyrin; ASD: Autism spectrum disease; ASD: Autism spectrum disorder; CB1R: Endocannabinoid receptor 1; CC: Coiled coil; DAG: Diacyl glycerol; DLC: Dynein light chain; DLGAP1-4: Discs large associated protein 1, 2, 3 and 4; DLGAPs: Discs large associated proteins; DLGs: Discs large scaffold proteins; EVH1: Ena/NASP Homology 1; FMR1: Fragile mental retardation 1; GH1: GKAP homology; GK: Guanylate kinase; GKAP: Guanylate kinase associated protein; GPCR: G-protein coupled receptors; Homer1-3: Homer family consisting of 3 proteins; IP3: Inositol 1,4,5-triphosphate; MAGUKs: Membrane-associated guanylate kinases; mGluRs: Metabotropic glutamate receptors; NMDA: N-methyl-D-aspartate; OCD: Obsessive compulsive disorder; PDZ: Zonula occludens-1 protein; PKA: Protein kinase A; PKC: Protein kinase C; PLC: Phospholipase C; PSD: Postsynaptic density; PTSD: Post-traumatic stress disorder; SAPAP1-4: SAP90/PSD95-associated protein 1-4; SH3: Src Homology 3; SHANK: Src-homology (SH3) and multiple ankyrin repeat domain proteins; SHANK1-3: SHANK proteins; SNV: Single nucleotide variation; SPN: SHANK/ProSAP
} 


\section{Acknowledgements}

We would like to thank and acknowledge Susanne Hoiberg for reading the manuscript.

\section{Funding}

This study is supported partially by a grant from the Lundbeck Foundation (AS) and a partial PhD fellowship for AHR from the ICMM, University of Copenhagen. The funding body had no influence in the design of the study, interpretation of data and writing the manuscript.

\section{Availability of data and materials}

Not applicable.

\section{Authors' contributions}

AHR has contributed significantly with ideas and reviewing the literature, putting figures together, and writing the preliminary version of the manuscript. HBR has contributed substantially with the design, making a new figure and revising the manuscript critically. AS has initiated the project and contributed significantly with ideas and by critically revising the manuscript as a whole. All authors have read and approved the final manuscript.

\section{Authors' information}

AHR is a PhD student in the Cellular and Genetic Medicine Program. HBR is Associate Professor in the Department of Biomedical Sciences interested in molecular and cellular neurobiology, AS is Associate Professor in the Medical Genetics Program, Department of Cellular and Molecular Medicine. AS is interested in genomic organization, gene expression and gene regulatory mechanisms in the brain, DLGAP4 gene, cytogenetics.

\section{Ethics approval and consent to participate}

Not applicable.

\section{Consent for publication}

Not applicable.

\section{Competing interests}

The authors declare that they have no competing interests.

\section{Publisher's Note}

Springer Nature remains neutral with regard to jurisdictional claims in published maps and institutional affiliations.

\section{Author details}

'Department of Cellular and Molecular Medicine, Faculty of Medical and Health Sciences, University of Copenhagen, DK-2200 Copenhagen, Denmark. ${ }^{2}$ Department of Biomedical Sciences, Faculty of Medical and Health Sciences, University of Copenhagen, DK-2200 Copenhagen, Denmark.

\section{Received: 11 May 2017 Accepted: 24 August 2017}

\section{Published online: 04 September 2017}

\section{References}

1. Kornau HC, Schenker LT, Kennedy MB, Seeburg PH. Domain interaction between NMDA receptor subunits and the postsynaptic density protein PSD-95. Science. 1995;269:1737-40.

2. Naisbitt S, Kim E, Tu JC, Xiao B, Sala C, Valtschanoff J, et al. Shank, a novel family of postsynaptic density proteins that binds to the NMDA receptor/ PSD-95/GKAP complex and cortactin. Neuron. 1999;23:569-82.

3. Chen L, Chetkovich DM, Petralia RS, Sweeney NT, Kawasaki Y, Wenthold RJ, et al. Stargazin regulates synaptic targeting of AMPA receptors by two distinct mechanisms. Nature. Macmillian Magazines Ltd. 2000;408:936-43.

4. Steiner P, Higley MJ, Xu W, Czervionke BL, Malenka RC, Sabatini BL. Destabilization of the postsynaptic density by PSD-95 serine 73 Phosphorylation inhibits spine growth and synaptic plasticity. Neuron. 2008;60:788-802.

5. Kim E. GKAP, a novel synaptic protein that interacts with the Guanylate Kinase-like domain of the PSD-95/SAP90 family of channel clustering molecules. J Cell Biol. 1997;136:669-78.

6. Naisbitt S, Kim E, Weinberg RJ, Rao A, Yang F-C, Craig AM, et al. Characterization of Guanylate Kinase-associated protein, a postsynaptic density protein at excitatory synapses that interacts directly with postsynaptic density-95/synapse-associated protein 90. J Neurosci. 1997;17:5687-96.

7. Chen M, Wan Y, Ade K, Ting J, Feng G, Calakos N. Sapap3 deletion anomalously activates short-term endocannabinoid-mediated synaptic plasticity. J Neurosci. 2011;31:9563-73.

8. Shin SM, Zhang N, Hansen J, Gerges NZ, Pak DTS, Sheng M, et al. GKAP orchestrates activity-dependent postsynaptic protein remodeling and homeostatic scaling. Nat Neurosci. 2012;15:1655-66.

9. Kajimoto Y, Shirakawa O, Lin X-H, Hashimoto T, Kitamura N, Murakami N, et al. Synapse-associated protein 90/postsynaptic density-95-associated protein (SAPAP) is expressed differentially in phencyclidine-treated rats and is increased in the nucleus accumbens of patients with schizophrenia. Neuropsychopharmacology. 2003;28:1831-9.

10. Pinto D, Pagnamenta AT, Klei L, Anney R, Merico D, Regan R, et al. Functional impact of global rare copy number variation in autism spectrum disorders. Nature. 2010;466:368-72.

11. Welch JM, Lu J, Rodriguiz RM, Trotta NC, Peca J, Ding J-D, et al. Corticostriatal synaptic defects and OCD-like behaviours in Sapap3-mutant mice. Nature. Nature Publishing Group. 2007;448:894-900.

12. Bienvenu OJ, Wang Y, Shugart YY, Welch JM, Grados MA, Fyer AJ, et al. Sapap3 and pathological grooming in humans: results from the OCD collaborative genetics study. Am J Med Genet B Neuropsychiatr Genet. 2009;150:710-20.

13. Ryu S, Oh S, Cho EY, Nam HJ, Yoo JH, Park T, et al. Interaction between genetic variants of DLGAP3 and SLC1A1 affecting the risk of atypical antipsychotics-induced obsessive-compulsive symptoms. Am J Med Genet B Neuropsychiatr Genet. 2011;156:949-59.

14. Minocherhomji S, Hansen C, Kim H-G, Mang Y, Bak M, Guldberg P, et al. Epigenetic remodelling and dysregulation of DLGAP4 is linked with earlyonset cerebellar ataxia. Hum Mol Genet. 2014;23:6163-76.

15. Chiu AW, Huang Y-L, Huan SK, Wang Y-C, Ju J-P, Chen M-F, et al. Potential molecular marker for detecting transitional cell carcinoma. Urology. 2002;60:181-5.

16. Tang ZY, Ye SL, Liu YK, Qin LX, Sun HC, Ye OH, et al. A decade's studies on metastasis of hepatocellular carcinoma. J Cancer Res Clin Oncol. 2004;130:187-96.

17. Stangeland B, Mughal AA, Grieg Z, Sandberg CJ, Joel M, Nygård S, et al. Combined expressional analysis, bioinformatics and targeted proteomics identify new potential therapeutic targets in glioblastoma stem cells. Oncotarget. 2015;6:26192-215.

18. Takeuchi M. SAPAPs. A family of PSD-95/SAP90-associated proteins localized at postsynaptic density. J Biol Chem. 1997;272:11943-51.

19. O'Connor EC, Bariselli S, Bellone C. Synaptic basis of social dysfunction: a focus on postsynaptic proteins linking group-I mGluRs with AMPARs and NMDARs. Eur J Neurosci. 2014;39:1114-29.

20. Tu JC, Xiao B, Yuan JP, Lanahan AA, Leoffert K, Li M, et al. Homer binds a novel proline-rich motif and links group I metabotropic glutamate receptors with IP3 receptors. Neuron. 1998:21:717-26.

21. Tu JC, Xiao B, Naisbitt S, Yuan JP, Petralia RS, Brakeman P, et al. Coupling of mGluR/Homer and PSD-95 complexes by the shank family of postsynaptic density proteins. Neuron. 1999;23:583-92.

22. Wu H, Reissner C, Kuhlendahl S, Coblentz B, Reuver S, Kindler S, et al. Intramolecular interactions regulate SAP97 binding to GKAP. EMBO J. 2000;19:5740-51.

23. Sabio G, Arthur JSC, Kuma Y, Peggie M, Carr J, Murray-Tait V, et al. p38gamma regulates the localisation of SAP97 in the cytoskeleton by modulating its interaction with GKAP. EMBO J. 2005:24:1134-45.

24. Manneville JB, Jehanno M, Etienne-Manneville S. Dlg1 binds GKAP to control dynein association with microtubules, centrosome positioning, and cell polarity. J Cell Biol. 2010;191:585-98.

25. Naisbitt S, Valtschanoff J, Allison DW, Sala C, Kim E, Craig AM, et al. Interaction of the postsynaptic density-95/guanylate kinase domainassociated protein complex with a light chain of myosin- $V$ and dynein. J Neurosci. 2000;20:4524-34.

26. Tong J, Yang H, Eom SH, Chun C, Im YJ. Structure of the GH1 domain of guanylate kinase-associated protein from Rattus Norvegicus. Biochem Biophys Res Commun. Elsevier Inc. 2014;452:130-5.

27. Waites CL, Specht CG, Härtel K, Leal-Ortiz S, Genoux D, Li D, et al. Synaptic SAP97 isoforms regulate AMPA receptor dynamics and access to presynaptic glutamate. J Neurosci. 2009;29:4332-45.

28. Li D, Specht CG, Waites CL, Butler-Munro C, Leal-Ortiz S, Foote JW, et al. SAP97 directs NMDA receptor spine targeting and synaptic plasticity. J Physiol. 2011;589:4491-510. 
29. Sun Q, Turrigiano GG. PSD-95 and PSD-93 play critical but distinct roles in synaptic scaling up and down. J Neurosci. 2011;31:6800-8. http://www. jneurosci.org/content/31/18/6800.long.

30. Stephan KE, Friston KJ, Frith CD. Dysconnection in schizophrenia: from abnormal synaptic plasticity to failures of self-monitoring. Schizophr Bull. 2009;35:509-27.

31. Kristiansen LV, Meador-Woodruff JH. Abnormal striatal expression of transcripts encoding NMDA interacting PSD proteins in schizophrenia, bipolar disorder and major depression. Schizophr Res. 2005;78:87-93.

32. Kristiansen LV, Beneyto M, Haroutunian V, Meador-Woodruff JH. Changes in NMDA receptor subunits and interacting PSD proteins in dorsolateral prefrontal and anterior cingulate cortex indicate abnormal regional expression in schizophrenia. Mol. Psychiatry. 2006;11:737-47.

33. Funk AJ, Rumbaugh G, Harotunian V, McCullumsmith RE, Meador-Woodruff $\mathrm{JH}$. Decreased expression of NMDA receptor-associated proteins in frontal cortex of elderly patients with schizophrenia. Neuroreport. 2009;20:1019-22.

34. Xing J, Kimura H, Wang C, Ishizuka K, Kushima I, Arioka Y, et al. Resequencing and association analysis of six PSD-95-related genes as possible susceptibility genes for schizophrenia and autism Spectrum disorders. Sci Rep. 2016;6:27491.

35. Uezato A, Kimura-Sato J, Yamamoto N, lijima Y, Kunugi H, Nishikawa T. Further evidence for a male-selective genetic association of synapse-associated protein 97 (SAP97) gene with schizophrenia. Behav Brain Funct. 2012;8:2.

36. Sato J, Shimazu D, Yamamoto N, Nishikawa T. An association analysis of synapse-associated protein 97 (SAP97) gene in schizophrenia. J Neural Transm. 2008;115:1355-65.

37. Xing J, Kimura H, Wang C, Ishizuka K, Kushima I, Arioka Y, et al. Resequencing and association analysis of six PSD-95-related genes as possible susceptibility genes for schizophrenia and autism Spectrum disorders. Sci Rep. 2016:6:1-8.

38. Colledge M, Dean RA, Scott GK, Langeberg LK, Huganir RL, Scott JD. Targeting of PKA to glutamate receptors through a MAGUK-AKAP complex. Neuron. 2000;27:107-19.

39. Shin H, Hsueh YP, Yang FC, Kim E, Sheng M. An intramolecular interaction between Src homology 3 domain and guanylate kinase-like domain required for channel clustering by postsynaptic density-95/SAP90. J Neurosci. 2000;20:3580-7.

40. Guilmatre A, Huguet $G$, Delorme R, Bourgeron T. The emerging role of SHANK genes in neuropsychiatric disorders. Dev Neurobiol. 2014;74:113-22.

41. Böckers TM, Mameza MG, Kreutz MR, Bockmann J, Weise C, Buck F, et al. Synaptic scaffolding proteins in rat brain: Ankyrin repeats of the multidomain shank protein family interact with the cytoskeletal protein afodrin. J Biol Chem. 2001;276:40104-12.

42. Lim S, Sala C, Yoon J, Park S, Kuroda S, Sheng M, et al. Sharpin, a novel postsynaptic density protein that directly interacts with the shank family of proteins. Mol Cell Neurosci. 2001;17:385-97.

43. Levine J, Willard M. Fodrin: axonally transported polypeptides associated with the internal periphery of many cells. J Cell Biol. 1981;90:631-42

44. Rantala JK, Pouwels J, Pellinen T, Veltel S, Laasola P, Mattila E, et al. SHARPIN is an endogenous inhibitor of $\beta 1$-integrin activation. Nat Cell Biol. 2011;13:1315-24.

45. McWilliams RR, Gidey E, Fouassier L, Weed SA, Doctor RB. Characterization of an ankyrin repeat-containing Shank2 isoform (Shank2E) in liver epithelial cells. Biochem J. 2004;380:181-91.

46. Quitsch A, Berhörster K, Liew CW, Richter D, Kreienkamp H-J. Postsynaptic shank antagonizes dendrite branching induced by the leucine-rich repeat protein Densin-180. J Neurosci. 2005;25:479-87.

47. Sheng M, Kim E. The shank family of scaffold proteins. J Cell Sci. 2000;113:1851-6.

48. Shiraishi Y, Mizutani A, Bito H, Fujisawa K, Narumiya S, Mikoshiba K, et al. Cupidin, an isoform of Homer/Nesl, interacts with the actin cytoskeleton and activated rho family small GTPases and is expressed in developing mouse cerebellar granule cells. J Neurosci. 1999;19:8389-400.

49. Mao L, Yang L, Tang Q, Samdani S, Zhang G, Wang JQ. The scaffold protein Homer1b/c links metabotropic glutamate receptor 5 to extracellular signalregulated protein kinase cascades in neurons. J Neurosci. 2005;25:2741-52.

50. Yamamoto K, Sakagami Y, Sugiura S, Inokuchi K, Shimohama S, Kato N. Homer 1a enhances spike-induced calcium influx via L-type calcium channels in neocortex pyramidal cells. Eur J Neurosci. 2005;22:1338-48.

51. Pieretti M, Zhang FP, Fu YH, Warren ST, Oostra BA, Caskey CT, et al. Absence of expression of the FMR-1 gene in fragile X syndrome. Cell. 1991;66:817-22.
52. Nimchinsky EA, Oberlander AM, Svoboda K. Abnormal development of dendritic spines in FMR1 knock-out mice. J Neurosci. 2001;21:5139-46.

53. Xiao B, Tu JC, Petralia RS, Yuan JP, Doan A, Breder CD, et al. Homer regulates the association of group 1 metabotropic glutamate receptors with multivalent complexes of Homer-related, synaptic proteins. Neuron. 1998;21:707-16.

54. Letts VA, Felix R, Biddlecome GH, Arikkath J, Mahaffey CL, Valenzuela A, et al. The mouse stargazer gene encodes a neuronal Ca2+-channel gamma subunit. Nat Genet. 1998;19:340-7.

55. Tselnicker I, Tsemakhovich VA, Dessauer CW, Dascal N. Stargazin modulates neuronal voltage-dependent $\mathrm{ca}(2+)$ channel ca(v)2.2 by a Gbetagammadependent mechanism. J Biol Chem. 2010;285:20462-71.

56. Noebels JL, Qiao X, Bronson RT, Spencer C, Davisson MT. Stargazer: a new neurological mutant on chromosome 15 in the mouse with prolonged cortical seizures. Epilepsy Res. 1990;7:129-35.

57. Menuz K, Nicoll RA. Loss of inhibitory neuron AMPA receptors contributes to ataxia and epilepsy in stargazer mice. J Neurosci. 2008;28:10599-603.

58. Chen L, El-Husseini A, Tomita S, Bredt DS, Nicoll RA. Stargazin differentially controls the trafficking of alpha-amino-3-hydroxyl-5-methyl-4isoxazolepropionate and kainate receptors. Mol Pharmacol. 2003;64:703-6.

59. Bats C, Groc L, Choquet D. The interaction between Stargazin and PSD-95 regulates AMPA receptor surface trafficking. Neuron. 2007;53:719-34.

60. Matsuda S, Kakegawa W, Budisantoso T, Nomura T, Kohda K, Yuzaki M. Stargazin regulates AMPA receptor trafficking through adaptor protein complexes during long-term depression. Nat Commun Nat Res. 2013;4:1-12.

61. Priel A, Kolleker A, Ayalon G, Gillor M, Osten P, Stern-Bach Y. Stargazin reduces desensitization and slows deactivation of the AMPA-type glutamate receptors. J Neurosci. 2005;25:2682-6.

62. Tomita S, Adesnik H, Sekiguchi M, Zhang W, Wada K, Howe JR, et al. Stargazin modulates AMPA receptor gating and trafficking by distinct domains. Nature. 2005:435:1052-8.

63. Turetsky D, Garringer E, Patneau DK. Stargazin modulates native AMPA receptor functional properties by two distinct mechanisms. J Neurosci. 2005;25:7438-48.

64. Cho C-H, St-Gelais F, Zhang W, Tomita S, Howe JR. Two families of TARP Isoforms that have distinct effects on the kinetic properties of AMPA receptors and synaptic currents. Neuron. 2007:55:890-904.

65. MacLean DM, Ramaswamy SS, Du M, Howe JR, Jayaraman V. Stargazin promotes closure of the AMPA receptor ligand-binding domain. J Gen Physiol. 2014;144:503-12.

66. Carbone AL, Plested AJR. Superactivation of AMPA receptors by auxiliary proteins. Nat Commun. 2016;7:1-12.

67. Yao I, lida J, Nishimura W, Hata Y. Synaptic localization of SAPAP1, a synaptic membrane-associated protein. Genes Cells. 2003:8:121-9.

68. Welch JM, Wang D, Feng G. Differential mRNA expression and protein localization of the SAP90/PSD-95-associated proteins (SAPAPS) in the nervous system of the mouse. J Comp Neurol. 2004;472:24-39.

69. Kindler S, Rehbein M, Classen B, Richter D, Böckers TM. Distinct spatiotemporal expression of SAPAP transcripts in the developing rat brain: a novel dendritically localized mRNA. Brain Res Mol Brain Res. 2004;126:14-21.

70. Pérez-Otaño I, Ehlers MD. Homeostatic plasticity and NMDA receptor trafficking. Trends Neurosci. 2005;28:229-38

71. Sheng M. Molecular organization of the postsynaptic specialization. Proc Natl Acad Sci U S A. 2001;98:7058-61.

72. Colledge M, Snyder EM, Crozier RA, Soderling JA, Jin Y, Langeberg LK, et al. Ubiquitination regulates PSD-95 degradation and AMPA receptor surface expression. Neuron. 2003;40:595-607.

73. $\mathrm{Na} C H$, Jones DR, Yang $Y$, Wang $X, X u Y$, Peng J. Synaptic protein ubiquitination in rat brain revealed by antibody-based ubiquitome analysis. J Proteome Res. 2012;11:4722-32.

74. Hung AY, Sung CC, Brito IL, Sheng M. Degradation of postsynaptic scaffold GKAP and regulation of dendritic spine morphology by the TRIM3 ubiquitin ligase in rat hippocampal neurons. PLoS One. 2010;5:1-11.

75. Dosemeci A, Jaffe $H$. Regulation of phosphorylation at the postsynaptic density during different activity states of $\mathrm{Ca} 2+/$ calmodulin-dependent protein kinase II. Biochem Biophys Res Commun. 2010;391:78-84.

76. Romorini S, Piccoli G, Jiang M, Grossano P, Tonna N, Passafaro M, et al. A functional role of postsynaptic density-95-guanylate kinase-associated protein complex in regulating shank assembly and stability to synapses. J Neurosci. 2004;24:9391-404.

77. Hanus C, Schuman EM. Proteostasis in complex dendrites. Nat Rev Neurosci. 2013;14:638-48 
78. Wan Y, Feng G, Calakos N. Sapap3 deletion causes mGluR5-dependent silencing of AMPAR synapses. J Neurosci. 2011;31:16685-91.

79. Hu JH, Park JM, Park S, Xiao B, Dehoff MH, Kim S, et al. Homeostatic scaling requires group I mGluR activation mediated by Homer1a. Neuron. 2010;68:1128-42.

80. Bertaso F, Roussignol G, Worley P, Bockaert J, Fagni L, Ango F. Homer1adependent crosstalk between NMDA and Metabotropic glutamate receptors in mouse neurons. PLoS One. 2010;5:1-6.

81. Brakeman PR, Lanahan AA, O'Brien R, Roche K, Barnes CA, Huganir RL, et al. Homer: a protein that selectively binds metabotropic glutamate receptors. Nature. 1997;386:284-8.

82. Mizutani A, Kuroda Y, Futatsugi A, Furuichi T, Mikoshiba K. Phosphorylation of Homer3 by calcium/calmodulin-dependent kinase II regulates a coupling state of its target molecules in Purkinje cells. J Neurosci. 2008;28:5369-82.

83. Jiang-Xie L-F, Liao H-M, Chen C-H, Chen Y-T, Ho S-Y, Lu D-H, et al. Autismassociated gene Dlgap2 mutant mice demonstrate exacerbated aggressive behaviors and orbitofrontal cortex deficits. Mol Autism. 2014;5:13.

84. Howlett AC, Barth F, Bonner TI, Cabral G, Casellas P, Devane WA, et al. International Union of Pharmacology. XXVII. Classification of cannabinoid receptors. Pharmacol Rev. 2002;54:161-202.

85. Roloff AM, Anderson GR, Martemyanov KA, Thayer SA. Homer 1a gates the induction mechanism for endocannabinoid-mediated synaptic plasticity. J Neurosci. 2010;30:3072-81.

86. Li JM, Lu CL, Cheng MC, Luu SU, Hsu SH, Chen CH. Genetic analysis of the DLGAP1 gene as a candidate gene for schizophrenia. Psychiatry Res. 2013:205:13-7.

87. Lichtenstein P, Yip BH, Björk C, Pawitan Y, Cannon TD, Sullivan PF, et al. Common genetic determinants of schizophrenia and bipolar disorder in Swedish families: a population-based study. Lancet. 2009;373:234-9.

88. Tang A-H, Alger BE. Homer protein-metabotropic glutamate receptor binding regulates endocannabinoid signaling and affects hyperexcitability in a mouse model of fragile X syndrome. J Neurosci. 2015;35:3938-45.

89. Malhotra AK, Pinals DA, Adler CM, Elman I, Clifton A, Pickar D, et al. Ketamine-induced exacerbation of psychotic symptoms and cognitive impairment in neuroleptic-free schizophrenics. Neuropsychopharmacology. 1997;17:141-50.

90. Kim JS, Kornhuber HH, Schmid-Burgk W, Holzmüller B. Low cerebrospinal fluid glutamate in schizophrenic patients and a new hypothesis on schizophrenia. Neurosci Lett. 1980;20:379-82.

91. Dracheva S, Marras SA, Elhakem SL, Kramer FR, Davis KL, Haroutunian V. $\mathrm{N}$-methyl-D-aspartic acid receptor expression in the dorsolateral prefrontal cortex of elderly patients with schizophrenia. Am J Psychiatry. 2001;158:1400-10.

92. Woo T-UW, Walsh JP, Benes FM. Density of glutamic acid decarboxylase 67 messenger RNA-containing neurons that express the N-methyl-D-aspartate receptor subunit NR2A in the anterior cingulate cortex in schizophrenia and bipolar disorder. Arch Gen Psychiatry. 2004;61:649-57.

93. Gardoni F, Mauceri D, Fiorentini C, Bellone C, Missale C, Cattabeni F, et al. CaMKIl-dependent phosphorylation regulates SAP97/NR2A interaction. J Biol Chem. 2003;278:44745-52.

94. Wang L, Piserchio A, Mierke DF. Structural characterization of the intermolecular interactions of synapse-associated protein-97 with the NR2B subunit of N-methyl-D-aspartate receptors. J Biol Chem. 2005;280:26992-6.

95. Sans N, Petralia RS, Wang YX, Blahos J, Hell JW, Wenthold RJ. A developmental change in NMDA receptor-associated proteins at hippocampal synapses. J Neurosci. 2000;20:1260-71.

96. Uezato A, Yamamoto N, Iwayama Y, Hiraoka S, Hiraaki E, Umino A, et al. Reduced cortical expression of a newly identified splicing variant of the DLG1 gene in patients with early-onset schizophrenia. Transl Psychiatry. 2015:5:e654.

97. Toyooka K, Iritani S, Makifuchi T, Shirakawa O, Kitamura N, Maeda K, et al. Selective reduction of a PDZ protein, SAP-97, in the prefrontal cortex of patients with chronic schizophrenia. J Neurochem. 2002;83:797-806.

98. Li JM, Lu CL, Cheng MC, Luu SU, Hsu SH, Chen $\mathrm{CH}$. Exonic resequencing of the DLGAP3 gene as a candidate gene for schizophrenia. Psychiatry Res. 2013;208:84-7.

99. Li J-M, Lu C-L, Cheng M-C, Luu S-U, Hsu S-H, Hu T-M, et al. Role of the DLGAP2 gene encoding the SAP90/PSD-95-associated protein 2 in schizophrenia. PLoS One. 2014:9:1-8.

100. Marshall CR, Noor A, Vincent JB, Lionel AC, Feuk L, Skaug J, et al. Structural variation of chromosomes in autism Spectrum disorder. Am J Hum Genet. 2008;82:477-88
101. Chien W-H, Gau SS-F, Liao H-M, Chiu Y-N, Wu Y-Y, Huang Y-S, et al. Deep exon resequencing of DLGAP2 as a candidate gene of autism spectrum disorders. Mol Autism. 2013;4:26.

102. Chertkow-Deutsher $Y$, Cohen H, Klein E, Ben-Shachar D. DNA methylation in vulnerability to post-traumatic stress in rats: evidence for the role of the postsynaptic density protein Dlgap2. Int J Neuropsychopharmacol. 2010;13:347-59.

103. Gilbertson MW, Shenton ME, Ciszewski A, Kasai K, Lasko NB, Orr SP, et al. Smaller hippocampal volume predicts pathologic vulnerability to psychological trauma. Nat Neurosci. 2002;5:1242-7.

104. Bremner JD, Vythilingam M, Vermetten E, Southwick SM, McGlashan T, Nazeer A, et al. MRI and PET study of deficits in Hippocampal structure and function in women with childhood sexual abuse and posttraumatic stress disorder. Am J Psychiatry. 2003;160:924-32.

105. Woon FL, Sood S, Hedges DW. Hippocampal volume deficits associated with exposure to psychological trauma and posttraumatic stress disorder in adults: a meta-analysis. Prog Neuro-Psychopharmacol Biol Psychiatry. 2010:34:1181-8.

106. Züchner S, Wendland JR, Ashley-Koch AE, Collins AL, Tran-Viet KN, Quinn K, et al. Multiple rare SAPAP3 missense variants in trichotillomania and OCD. Mol Psychiatry. Nature Publishing Group. 2009;14:6-9.

107. Hertz JM, Sivertsen B, Silahtaroglu A, Bugge M, Kalscheuer V, Weber A, et al. Early onset, non-progressive, mild cerebellar ataxia co-segregating with a familial balanced translocation t(8;20)(p22;q13). J Med Genet. 2004;41:1-3.

108. Hashimoto K, Fukaya M, Qiao X, Sakimura K, Watanabe M, Kano M. Impairment of AMPA receptor function in cerebellar granule cells of ataxic mutant mouse stargazer. J Neurosci. 1999;19:6027-36.

109. Coesmans M, Smitt PAS, Linden DJ, Shigemoto R, Hirano T, Yamakawa Y, et al. Mechanisms underlying cerebellar motor deficits due to mGluR1autoantibodies. Ann Neurol. 2003;53:325-36.

110. Guergueltcheva V, Azmanov DN, Angelicheva D, Smith KR, Chamova T, Florez $\mathrm{L}$, et al. Autosomal-recessive congenital cerebellar ataxia is caused by mutations in metabotropic glutamate receptor 1. Am J Hum Genet. 2012;91:553-64

111. Aoyama S, Shirakawa O, Ono H, Hashimoto T, Kajimoto $Y$, Maeda K. Mutation and association analysis of the DAP-1 gene with schizophrenia. Psychiatry Clin Neurosci. 2003;57:545-7.

112. Pickard BS, Malloy MP, Clark L, Lehellard S, Ewald HL, Mors O, et al. Candidate psychiatric illness genes identified in patients with pericentric inversions of chromosome 18. Psychiatr Genet. 2005;15:37-44.

113. Kirov G, Pocklington AJ, Holmans P, Ivanov D, Ikeda M, Ruderfer D, et al. De novo CNV analysis implicates specific abnormalities of postsynaptic signalling complexes in the pathogenesis of schizophrenia. Mol Psychiatry. 2012;17:142-53.

114. Roselli F, Livrea P, Almeida OFX. CDK5 is essential for soluble amyloid $\beta$-induced degradation of GKAP and remodeling of the synaptic actin cytoskeleton. PLoS One. 2011;6:1-14.

115. Mathias SR, Knowles EEM, Kent JW, McKay DR, Curran JE, de Almeida MAA, et al. Recurrent major depression and right hippocampal volume: a bivariate linkage and association study. Hum Brain Mapp. 2016;37:191-202.

116. Schütt J, Falley K, Richter D, Kreienkamp H-J, Kindler S. Fragile X mental retardation protein regulates the levels of scaffold proteins and glutamate receptors in postsynaptic densities. J Biol Chem. 2009;284:25479-87.

117. Liu S, Zhang Y, Bian H, Li X. Gene expression profiling predicts pathways and genes associated with Parkinson's disease. Neurol Sci. 2016;37:73-9.

118. Kim Y, Zhang Y, Pang K, Kang H, Park H, Lee Y, et al. Bipolar disorder associated microRNA, miR-1908-5p, regulates the expression of genes functioning in neuronal Glutamatergic synapses. Exp Neurobiol. 2016;25:296-306. 